\title{
Anticancer Activities of Sesewanua Leaf Extracts (Clerodendrum fragrans (Vent.) Willd) Against A549 Lung Cancer Cell
}

\author{
Elisabeth Natalia Barung ${ }^{1 *}$ (D), Donald Emilio Kalonio ${ }^{1}$ D, Yos Banne ${ }^{1}$ iD Norma Tiku Kambuno $^{2}$ (D) \\ ${ }^{1}$ Departement of Pharmacy, Politeknik Kesehatan Kementerian Kesehatan Manado, Manado, Indonesia; ${ }^{2}$ Department of \\ Medical Laboratory Technology, Poltekkes Kemenkes Kupang, Kupang, Indonesia
}

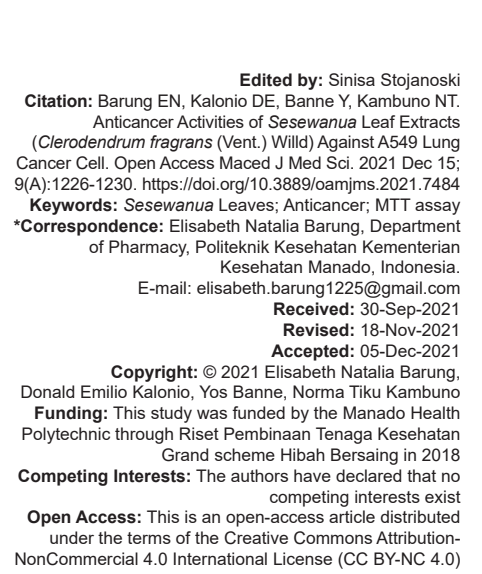

Abstract

BACKGROUND: Cancer is one of the leading causes of non-communicable diseases in the world, with about 10 million deaths worldwide in 2020. Lung cancer was the most common type of cancer and the highest cause of death. Therapy for lung cancer can be either conventional therapy or molecular targeted therapy that has many limitations.

AIM: It is, therefore, important to explore new sources of anticancer activity, including those from plants. One plant that is thought to have anticancer activity is Sesewanua (Clerodendrum fragrans [Vent.] Willd. Syn. Clerodendrum chinense [Osbeck] Mabb., Family Lamiaceae).

METHODS: This research is a laboratory experiment. The sample used is the C. fragrans leaves obtained in Malalayang I Timur Village, Malalayang District, Manado City, North Sulawesi Province, while the subjects in this study were A549 lung cancer cells from Cell-Culture Laboratory, Faculty of Pharmacy, Universitas Padjadjaran Bandung. Anticancer activity test was using the MTT tetrazolium assay method. Data in the form of a percentage (\%) inhibition of cell proliferation, then determined the value the concentration of $50 \%$ proliferation inhibition (IC50) using a computer program online.

RESULTS: The results showed that ethanol extract, hexane fraction, ethyl acetate fraction, and water-soluble fraction of $\mathrm{C}$. fragrans had anticancer activity on A549 lung cancer cells. The smallest IC50 value is indicated by ethyl acetate fraction $(191,165 \mathrm{ppm})$, which is categorized as moderately active.

\section{Introduction}

Cancer is one of the leading non-communicable diseases causing death worldwide. In 2020, cancer caused the deaths of almost 10 million people worldwide [1]. In Indonesia, the prevalence of cancer in all age groups in 2018 was $1.79 \%$ and in North Sulawesi Province, at $1.71 \%$ [2]. Lung cancer is the most common type of cancer and the highest cause of death in the global population. Recorded in 2020 , lung cancer caused the death of 1.8 million people from total cancer death worldwide [1].

The choice of lung cancer therapy depends on the type, stage, health, and age of lung cancer patients, which can be conventional therapy (surgery, platinum-based chemotherapy, and radiotherapy) or molecular targeted therapy [3], [4], [5], [6]. Reportedly, the 5-year survival rate in lung cancer patients receiving conventional therapy is $18 \%$ and lower than most other types of cancer [4], [7]. Molecular targeted therapy provides hope with the availability of new drugs to reduce morbidity and mortality from lung cancer. However, this therapy has limitations in the number of drugs, some are still in the clinical trial stage and require appropriate biomolecular diagnostic knowledge to ensure the success of therapy [4], [6]. It is, therefore, important to explore new sources of anticancer activity, including those from plants.

Since ancient times, plants have been used in cancer treatment and become a source of anticancer compounds with various mechanisms of action [8], [9] A plant that is thought to have anticancer activity is Sesewanua plants (Clerodendrum fragrans [Vent.] Willd. Syn. Clerodendrum chinense [Osbeck] Mabb., Family Lamiaceae). The people of North Sulawesi traditionally use Sesewanua ( $C$. fragrans [Vent.] Willd) leaves as an anti-inflammation and antipyretic medication [10]. There is no adequate scientific information about the activity of Sesewanua plants as anticancer. Kalonio et al. [11] report that there are 12 plants from the genus Clerodendrum that have been shown to have in vitro and in vivo anticancer activities.

Sesewanua (C. fragrans [Vent.] Willd leaves are reported to contain beta-sitosterol, clerosterol, daucosterol, caffeic acid, acteoside, leucoseceptoside A, kaempferol, and 5,4'-dihydroxy-kaempferol-7-Obeta-rutinoside [12]. Molecular docking simulation results show that acteoside contained in the genus Clerodendrum can bind to the target of cancer proteins so that it has the potential as an anticancer [13]. 
Kaempferol can inhibit the growth of pancreatic cancer cells Miapaca-2, Panc-1, and SNU-213 [14]. As for beta-sitosterol and daucosterol compounds in benzene extract of leaf Grewia tiliaefolia showed anticancer activity in A549 lung cancer cells [15]. These things can illustrate that the Sesewanua (C. fragrans [Vent.] Willd) leaves are thought to have potential as anticancer.

This study aims to evaluate the anticancer activity of Sesewanua leaves (C. fragrans [Vent.] Willd) extracts and fractions against A549 lung cancer cells using the method MTT tetrazolium assay, and determine the $50 \%$ inhibition concentration of it.

\section{Methods}

\section{C. fragrans leaves collection and processing}

Sesewanua leaves (C. fragrans [Vent.] Willd) were collected from Malalayang I Timur village, Malalayang District, Manado City, North Sulawesi Province.

\section{Extraction and fractionation}

Sesewanua leaves powder (C. fragrans [Vent.] Willd) was extracted by maceration method using $70 \%$ ethanol solvent. As a result of the extraction process, ethanol extract was obtained in a yield of $27.8 \%$.

Fractionation of the ethanolic extract of the Setswana (C. fragrance [Vent.] Willd) leaves using a liquid extraction method with n-hexane and ethyl acetate as solvents, respectively [16]. Fractionation results were obtained by $1.03 \mathrm{~g}$-hexane fraction; ethyl acetate fraction $1.90 \mathrm{~g}$, and water fraction $7.00 \mathrm{~g}$.

\section{test (BSLT) \\ Toxicity test with the brine shrimp lethality}

Eggs of Artemia salina hatched in artificial seawater $(\mathrm{NaCl} 3.8 \%)$ for $48 \mathrm{~h}$ so that adult shrimp called nauplii are obtained. Extracts and fractions were dissolved in DMSO, and diluted with artificial seawater to obtain a concentration of 10; 100; and $1000 \mu \mathrm{g} / \mathrm{ml}$ in $5 \mathrm{ml}$ of solution. DMSO concentration in the solution should not be more than $50 \mu \mathrm{l} / 5 \mathrm{ml}$. A solution of $50 \mu \mathrm{l}$ of DMSO in $5 \mathrm{ml}$ of artificial seawater was used as a control. A total of ten nauplii were added to the sample solution and control. After $24 \mathrm{~h}$, the number of dead nauplii was observed and the percentage of death was calculated [17], [18]. The $\mathrm{LC}_{50}$ value was calculated using a regression analysis between the log concentration $(x)$ and the probit value $(y)$ using a computer program available online on the website https://www.aatbio.com/ tools/linear-logarithmic-semi-log-regression-onlinecalculator

\section{Anticancer activity using the MTT} tetrazolium assay method

A total of $50 \mu$ l of cell suspension in RPMI-1640 medium with a density of $5 \times 10^{3} /$ well [19] inserted into a 96-well plate and incubated at $37^{\circ} \mathrm{C}$ in an incubator flowed $\mathrm{CO}_{2} 5 \%$ for $24 \mathrm{~h}$. Furthermore, cell cultures were treated each with extracts and fractions (concentrations of $1000 ; 100 ; 10 ; 1$; and $0.1 \mathrm{ppm}$ ), cisplatin (100; 10; 1 ; $0.1 ; 0.01 \mathrm{ppm}$ ), and controls (cells with medium), then incubated at $37^{\circ} \mathrm{C}$ in an incubator which flowed $\mathrm{CO}_{2} 5 \%$ for $24 \mathrm{~h}$. After the incubation period, 10uL CCK-8 was added to each well and pre-incubated for $3 \mathrm{~h}$. After adding $100 \mu \mathrm{L}$ of $0.1 \mathrm{~N} \mathrm{HCl}$, the absorption was measured at a wavelength of $450 \mathrm{~nm}$ and a reference wavelength of $650 \mathrm{~nm}$ [20]. The percentage (\%) of cell proliferation inhibition was calculated using the equation [21]:

$$
\begin{aligned}
& \% \text { Proliferation Inhibition }= \\
& \left(1-\frac{\text { Absorbance of experimental well })}{\text { Absorbance of negative control well }}\right) \times 100
\end{aligned}
$$

\section{Data analysis}

The inhibition concentration of $50 \%\left(\mathrm{IC}_{50}\right)$ value was determined using a computer program online available on the website https://www.aatbio.com/tools/ ic50-calculator with a value of $x=$ concentration and $y$ value $=$ percentage $(\%)$ of proliferation inhibition .

\section{Results and Discussion}

\section{Extraction and fractionation}

Sesewanua (C. fragrans [Vent.] Willd) leaves powder was extracted by maceration. Ethanol was used as a solvent which was expected to attract all the compounds in the sample. Ethanol with a maximum water content of $30 \%$ could extract tannins, polyphenols, polyacetylenes, flavonoids, terpenoids, sterols, and alkaloids from natural products [22].

\section{Preliminary toxicity test with BSLT method}

The results of toxicity test extracts, n-hexane, ethyl acetate, and water fraction of Sesewanua (C. fragrans [Vent.] Willd) leaves by BSLT method are shown in Table 1.

Data in Table 1 show that the values of $\mathrm{LC}_{50}$ extracts and fractions of Sesewanua (C. fragrans [Vent.] Willd) leaves are sequentially ethyl acetate 
fraction $<$ n-hexane fraction $<$ ethanol extract $<$ water fraction. Pertiwi et al. reported that the ethyl acetate extract from the leaves of plants of the same genus as C. paniculatum L. had an $\mathrm{LC}_{50}$ value of $29.182 \mathrm{ppm}$ by BSLT test [23]. The BSLT was a simple bioassay for natural product research, especially for assessing the potential toxicity and biological activity of natural products [23]. According to the Meyer et al., plant extracts were considered toxic if they had $\mathrm{LC}_{50}$ $<1000$ ppm [17]. The result in Table 1, extracts and fractions of Sesewanua leaves were toxic so that the potential for further investigation is anticancer drugs.

Table 1: Percentage of larvae mortality, probit values, and $\mathrm{LC}_{50}$ values due to ethanol extract, $n$-hexane fraction, ethyl acetate, and water fraction of Sesewanua (Clerodendrum fragrans [Vent.] Willd) leaves larvae Artemia salina

\begin{tabular}{|c|c|c|c|c|c|}
\hline \multirow[t]{2}{*}{ S. No. } & \multirow[t]{2}{*}{ Treatment } & \multirow{2}{*}{$\begin{array}{l}\text { Concentration } \\
(\mu \mathrm{g} / \mathrm{ml})\end{array}$} & \multirow{2}{*}{$\begin{array}{l}\% \text { Mortality of } \\
\text { Larvae }\end{array}$} & \multirow[t]{2}{*}{ Probit } & \multirow{2}{*}{$\mathrm{LC}_{50}(\mu \mathrm{g} / \mathrm{ml})$} \\
\hline & & & & & \\
\hline 1. & Control & - & 0.00 & 0 & -- \\
\hline \multirow[t]{3}{*}{2.} & Ethanol & 10 & 3.33 & 3.12 & 60.26 \\
\hline & Extract & 100 & 76.67 & 5.74 & \\
\hline & & 1000 & 100.00 & 8.09 & \\
\hline \multirow[t]{3}{*}{3.} & n-Hexan & 10 & 36.67 & 4.67 & 33.88 \\
\hline & Fraction & 100 & 96.67 & 6.88 & \\
\hline & & 1000 & 100.00 & 8.09 & \\
\hline \multirow[t]{3}{*}{4.} & Ethyl Acetate & 10 & 86.67 & 6.13 & 26.92 \\
\hline & Fraction & 100 & 93.33 & 6.48 & \\
\hline & & 1000 & 100.00 & 8.09 & \\
\hline \multirow[t]{3}{*}{5.} & Water Soluble & 10 & 10.00 & 3.72 & 186.21 \\
\hline & Fraction & 100 & 33.33 & 4.56 & \\
\hline & & 1000 & 83.33 & 5.95 & \\
\hline
\end{tabular}

\section{Anticancer activity test with MTT tetrazolium assay method}

Activity test results of extract, n-hexane fraction, ethyl acetate, and water fraction of Sesewanua (C. fragrans [Vent.] Willd) leaves by method MTT tetrazolium assay are shown in Figure 1.

The results were used a computer program online available from the website https://www.aatbio. com/tools/ic50-calculator as shown in Figure 2. The $I_{50}$ value of ethanol extracts is $436.912 \mathrm{ppm}$; n-hexane fraction 295.710 ppm; ethyl acetate fraction 191.165 ppm; and the water fraction of 373.783 ppm. The $\mathrm{NCl}$ criteria modified by Srisawat et al. [24] and stated that the extracts with $\mathrm{IC}_{50} \leq 20 \mathrm{ppm}$ have high activity; IC ${ }_{50} 21-200$ ppm, moderate activity; $I_{50} 201-$ 500 ppm, weak activity; and $\mathrm{IC}_{50}>500$ ppm is not active. Based on these criteria, the ethyl acetate fraction of Sesewanua ( $C$. fragrans [Vent.] Willd) leaves could be said to have moderate anticancer activity. Cisplatin as lung cancer first-line chemotherapy [3] from the results of this study has a high activity because it has $\mathrm{IC}_{50} 8294 \mathrm{ppm}$.

In Figure 2, we can observe changes in A549 lung cancer cell morphology after exposure to cisplatin, extracts and fractions of Sesewanua (C. fragrans [Vent.] Willd) leaves. Viable cancer cells line was characterized by the formation of a monolayer adherent cell layer on the base surface of cell culture tubes [25], [26], and dead cells will appear to float in the medium. Changes in the morphology of cancer cells can be used to observe the type of cell death, whether through the mechanism of apoptosis or necrosis [27], [28]. Cisplatin, which includes platinum-based drugs, causes cell death through the mechanism of apoptosis by inducing genotoxic stress which activates a variety of transduction signal [29]. Further research is still needed to determine the mechanism of cancer cell death due to exposure to extracts and fraction of Sesewanua (C. fragrans [Vent.] Willd) leaves.



Figure 1: The relationship between the percentage (\%) of proliferation inhibition $(y)$ and concentration $(x)$ administration of ethanol extract (a), n-hexane (b), ethyl acetate (c), water (d) of Sesewanua (Clerodendrum fragrans [Vent.] Willd) leaves, and cisplatin (e) (https://www.aatbio.com/tools/ic50-calculatorCalculation)

Kalonio et al. suggested that there were 12 plants from the genus Clerodendrum having anticancer activities both in vitro and in vivo [11]. Some plants from the Lamiaceae family such as Pogostemon heyneanus, Plectranthus amboinicus [30], and Ocimum sanctum [31] were reported to have anticancer activity. The research data support the results of the present study that extracts and fractions of Sesewanua (C. fragrans [Vent.] Willd) leaves have potential as anticancer in A549 lung cancer cells. 


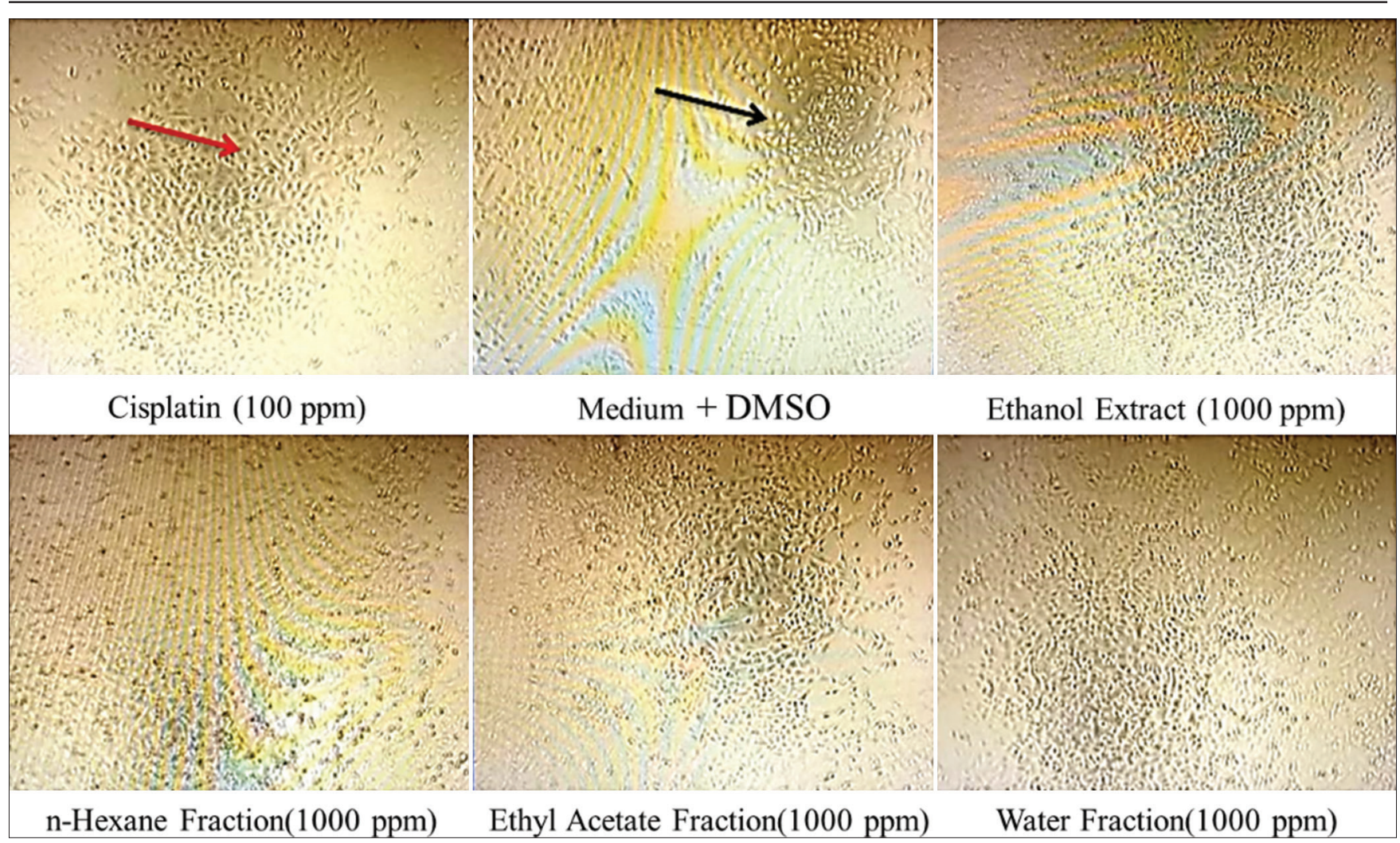

Figure 2: A549 lung cancer cell morphology after exposure to cisplatin, extract and fraction of Sesewanua leaves (Clerodendrum fragrans [Vent.] Willd)

\section{Conclusion}

Based on the results of the study, ethanol extract, hexane fraction, ethyl acetate fraction, and water soluble fraction of Sesewanua (C. fragrans [Vent.] Willd) leaves (C. fragrans [Vent.] Willd) have anticancer activity on A549 lung cancer cells. The value of IC50 proliferation of A549 lung cancer cells respectively ethyl acetate fraction is lower than hexane fraction, then IC50 value of hexane fraction is lower than water fraction, and IC50 value of water fraction is lower than ethanol extract. The smallest IC50 value is indicated by ethyl acetate fraction (191, $165 \mathrm{ppm}$ ), which is categorized as moderately active.

\section{Ethical Approvals}

This research met the ethical requirements to be carried out from the Ethics Committee of Politeknik Kesehatan Kementerian Kesehatan Manado, Indonesia.

\section{References}

1. WHO. Cancer. Geneva: WHO; 2021. Available from: https:// www.who.int/news-room/fact-sheets/detail/cancer accessed on 2021 Nov 08]

2. Riskesdas. Laporan Nasional Riskesdas 2018. Badan Penelitian dan Pengembangan Kesehatan, Kementerian Kesehatan RI. Jakarta: Riskesdas; 2018.

3. Bandyopadhyay A, Das T, Yeasmin S. Nanoparticles in Lung Cancer Therapy-Recent Trends. New York: Springer; 2015. p. 1-15.

4. Cagle PT, Chirieac LR. Advances in treatment of lung cancer with targeted therapy. Arch Pathol Lab Med. 2012;136:504-9.

5. Toschi L, Rossi S, Finocchiaro G, Santoro A. Non-small cell lung cancer treatment ( $r$ )evolution: Ten years of advances and more to come. Ecancer. 2017;11(787):1-14

6. Waqar SN, Morgensztern D. Treatment advances in small cell lung cancer (SCLC). Pharmacol Ther. 2017;180:16-23. https:// doi.org/10.1016/j.pharmthera.2017.06.002 PMid:28579387

7. Siegel R, Miller K, Jemal A. Cancer statistics, 2017. CA Cancer J Clin. 2017;67(1):7-30. https://doi.org/10.3322/caac.21387 PMid:28055103

8. Cragg GM, Newman DJ. Plants as a source of anti-cancer agents. J Ethnopharmacol. 2005;100(1-2):72-9. https://doi. org/10.1016/j.jep.2005.05.011

PMid:16009521

9. Ashraf A, Sarfraz RA, Rashid MA, Mahmood A, Shahid M, Noor N. Chemical composition, antioxidant, antitumor, anticancer and cytotoxic effects of psidium guajava leaf extracts. Pharm Biol. 2016;54(10):1971-81. https://doi.org/10.3109/1388 0209.2015.1137604 PMid:26841303

10. Arini DI, Kinho J. The diversity of medicinal plants in the coastal forest of the Tangkoko Nature Reserve. J WASIAN. 2015;2(1):1-8.

11. Kalonio DE, Hendriani $R$, Barung EN. Anticancer activity of plants of the genus clerodendrum (lamiaceae). Tradit Med J. 
2017;22(3):182-9.

12. Gao L, Wei $X$, He $Y$. Studies on chemical constituents in leafs of clerodendron fragrans. Zhongguo Zhong Yao Za Zhi. 2003;28(10):948-51.

PMid:15620185

13. Gogoi B, Gogoi D, Silla Y, Kakoti BB, Bhau BS. Network pharmacology-based virtual screening of natural products from clerodendrum species for identification of novel anti-cancer therapeutics. Mol Biosyst. 2017;13(2):406-16. https://doi. org/10.1039/c6mb00807k

PMid:28070575

14. Lee J, Kim JH. Kaempferol inhibits pancreatic cancer cell growth and migration through the blockade of EGFR-related pathway in vitro. PLoS One. 2016;11(5):e0155264. https://doi. org/10.1371/journal.pone.0155264 PMid:27175782

15. Rajavel T, Mohankumar R, Archunan G, Ruckmani K, Devi KP. Beta sitosterol and daucosterol (phytosterols identified in grewia tiliaefolia) perturbs cell cycle and induces apoptotic cell death in A549 cells. Sci Rep. 2017;7(1):3418. https://doi.org/10.1038/ s41598-017-03511-4 PMid:28611451

16. Zhao S, Zhang L, Gao P, Shao Z. Isolation and characterisation of the isoflavones from sprouted chickpea seeds. Food Chem. 2009;114(3):869-73.

17. Meyer B, Ferrigni N, Putnam J, Jacobsen L, Nichols D McLaughlin J. Brine shrimp: A convenient general bioassay for active plant constituents. Planta Med. 1982;45(1):31-4. https:// doi.org/10.1055/s-2007-971236

PMid:17396775

18. Kumar PS, Febriyanti RM, Sofyan FF, Luftimas DE, Abdulah R. Anticancer potential of Syzygium aromaticum L. in MCF-7 human breast cancer cell lines. Pharmacognosy Res. 2014;6(4):350-4. https://doi.org/10.4103/0974-8490.138291 PMid:25276075

19. Lee CJ, Yue CH, Lin YJ, Lin YY, Kao SH, Liu JY, et al. Antitumor activity of acriflavine in lung adenocarcinoma cell line A549. Anticancer Res. 2014;34(11):6467-72.

PMid:25368247

20. Abdulah R, Faried A, Kobayashi K, Yamazaki C, Suradj $\mathrm{EW}$, Ito $\mathrm{K}$, et al. Selenium Enrichment of broccoli sprout extract increases chemosensitivity and apoptosis of LNCaP prostate cancer cells. BMC Cancer. 2009;9(4):414. https://doi. org/10.1186/1471-2407-9-414
PMid:19943972

21. Florento L, Matias R, Tuaño E, Santiago K, Dela Cruz F, Tuazon A. Comparison of cytotoxic activity of anticancer drugs against various human tumor cell lines using in vitro cell-based approach. Int J Biomed Sci. 2012;8(1):76-80. PMid:23675259

22. Tiwari P, Kumar B, Kaur M, Kaur G, Kaur H. Phytochemical screening and extraction-a review. Int Pharm Sci. 2011;1(1):98-106.

23. Pertiwi D, Hafiz I, Leny L. Potential bioactivities of ethanol, ethyl acetate and $\mathrm{N}$-hexane extracts from pagoda leaves (Clerodendrum paniculatum L.). Rasayan J Chem. 2020;13(4):2313-6.

24. Srisawat $T$, Chumkaew $P$, Heed-Chim W, Sukpondma $Y$, Kanokwiroon K. Phytochemical screening and cytotoxicity of crude extracts of vatica diospyroides symington type LS. Trop J Pharm Res. 2013;12(1):71-6.

25. Foster KA, Oster CG, Mayer MM, Avery ML, Audus KL. Characterization of the A549 CELL LINE AS A Type II pulmonary epithelial cell model for drug metabolism. Exp Cell Res. 1998;243(2):359-66. https://doi.org/10.1006/excr.1998.4172 PMid:9743595

26. Shanmugapriya, Chen Y, Kanwar JR, Sasidharan S. Effects of calophyllum inophyllum fruit extract on the proliferation and morphological characteristics of human breast cancer cells MCF-7. Asian Pac J Trop Dis. 2016;6(4):291-7.

27. Majno G, Joris I. Apoptosis, oncosis, and necrosis. An overview of cell death. Am J Pathol. 1995;146(1):3-15. PMid:7856735

28. Muniaraj S, Subramanian V, Srinivasan P, Palani M. In silico and in vitro studies on lyngbya majuscula using against lung cancer cell line (A549). Pharmacogn J. 2018;10(3):421-8.

29. Dasari S, Tchounwou PB. Cisplatin in cancer therapy: Molecular mechanisms of action. Eur J Pharmacol. 2014;740:364-78. https://doi.org/10.1016/j.ejphar.2014.07.025 PMid:25058905

30. Rai V, Pai VR, Kedilaya P. A preliminary evaluation of anticancer and antioxidant potential of two traditional medicinal plants from lamiaceae-pogostemon heyneanus and Plectranthus amboinicus. J Appl Pharm Sci. 2016;6(8):73-8.

31. Iqbal J, Abbasi BA, Mahmood T, Kanwal S, Ali B, Shah SA, et al Plant-derived anticancer agents: A green anticancer approach. Asian Pac J Trop Biomed. 2017;7(12):1129-50. 